\title{
Measuring Economic Preparation for Retirement: Income Versus Consumption
}

\author{
Michael D. Hurd and Susann Rohwedder
}




\title{
Measuring Economic Preparation for Retirement: Income Versus Consumption
}

\author{
Michael D. Hurd \\ RAND, NBER, MEA and NETSPAR \\ Susann Rohwedder \\ RAND and NETSPAR
}

September 2015

\author{
Michigan Retirement Research Center \\ University of Michigan \\ P.O. Box 1248 \\ Ann Arbor, MI 48104 \\ www.mrrc.isr.umich.edu
}

(734) 615-0422

\section{Acknowledgements}

The research reported herein was performed pursuant to a grant from the U.S. Social Security

Administration (SSA) funded as part of the Retirement Research Consortium through the University of Michigan Retirement Research Center (5 RRC08098401-07). The opinions and conclusions expressed are solely those of the author(s) and do not represent the opinions or policy of SSA or any agency of the Federal Government. Neither the United States Government or any agency thereof, or any of their employees, makes any warranty, express or implied, or assumes any legal liability or responsibility for the accuracy, completeness, or usefulness of the contents of this report. Reference herein to any specific commercial product, process or service by trade name, trademark, manufacturer, or otherwise does not necessarily constitute or imply endorsement, recommendation or favoring by the United States Government or any agency thereof.

\section{Regents of the University of Michigan}

Michael J. Behm, Grand Blanc; Mark J. Bernstein, Ann Arbor; Laurence B. Deitch, Bloomfield Hills; Shauna Ryder Diggs, Grosse Pointe; Denise Ilitch, Bingham Farms; Andrea Fischer Newman, Ann Arbor; Andrew C. Richner, Grosse Pointe Park; Katherine E. White, Ann Arbor; Mark S. Schlissel, ex officio 


\title{
Measuring Economic Preparation for Retirement: Income Versus Consumption
}

\begin{abstract}
The income replacement rate (income immediately following retirement divided by income immediately preceding retirement) has become widely used as a measure of economic preparation for retirement. Yet a number of relevant issues are not adequately captured by the replacement rate concept. These include nontraditional transitions from full employment to full retirement, nonparallel transitions by the members of a married couple, and the ability to finance consumption out of savings. In this paper we estimate several measures of the income replacement rate that address some of these issues. Then we compare these income replacement rates with a consumption-based measure of economic preparation that takes into account the ultimate consequences for the retirement-to-death consumption path. Broadly speaking, the measure finds whether a household has, with high probability, the resources to finance a trajectory of spending from shortly following retirement until death. Our preferred measure of the income replacement rate somewhat understates the percentage of single persons adequately prepared for retirement, but it grossly understates the percentage of married persons adequately prepared. Furthermore, there is little relationship between the income replacement rate and our consumption-based measure. The implication is that the income replacement rate is of little use for assessing economic preparation for retirement: the chances that someone with a low income replacement rate is well prepared are not much different from the chances that someone with a high income replacement rate is well prepared.
\end{abstract}

\section{Citation}

Hurd, Michael D. and Susann Rohwedder. 2015 "Measuring Economic Preparation for Retirement: Income Versus Consumption.” Ann Arbor, MI. University of Michigan Retirement Research Center (MRRC) Working Paper, WP 2015-332.

http://www.mrrc.isr.umich.edu/publications/papers/pdf/wp332.pdf

\section{Authors' acknowledgements}

This work was supported by a grant from the Social Security Administration through the Michigan Retirement Research Center (UM15-10). The findings and conclusions expressed are solely those of the author and do not represent the views of the Social Security Administration, any agency of the Federal government, or the Michigan Retirement Research Center. Joanna Carroll provided excellent programming assistance. 


\section{Background}

In the mid-20th century, as policymakers considered Social Security benefit adjustments that were both affordable and provided a meaningful level of income security, private-sector decision makers sought the answers to similar questions regarding employer-provided defined-benefit pensions. Metrics were needed to express the benefits of Social Security and private-sector pension income. The income replacement rate (income immediately following retirement divided by income immediately preceding retirement) became widely used as a measure of economic preparation for retirement by financial advisors and in the popular financial literature. For example, various online financial calculators suggest that retirement income replacement rates should exceed 70 percent.

The target retirement replacement rate is meant to serve as a rule of thumb to provide a simple starting point for individuals and households in their financial planning for retirement. Prior research has investigated various conceptual issues concerning the implementation of the retirement replacement rate and its extensions to deal with the shift from defined benefit (DB) retirement resources and to take into account various types of financial and real assets. ${ }^{1}$ Recommended target replacement rates tend to range between 65 and 95 percent, depending on the source considered. They are less than 100 percent, because for most retired households taxes are lower, work-related expenses are eliminated, and there is less need to save. The large range reflects, in part, differences in definitions of the replacement rate used (Biggs and Springstead, 2008), but also the fact that the appropriate target replacement rate may differ across households, depending on marital status, number of earners and income group (Munnell, Webb, and Delorme, 2006), or also on whether the household has children (Scholz and Seshadri, 2009). ${ }^{2}$

The retirement replacement rate continues to occupy an important role in retirement planning and assessments of adequacy of retirement resources. For example, the National Retirement Risk Index produced by the Retirement Research Center at Boston College (Munnell et al., 2006) computes

\footnotetext{
${ }^{1}$ See for example, Boskin and Shoven (1984); Au, Mitchell and Phillips (2004); Munnell and Soto (2005); Munnell, Golub-Sass, and Webb (2007); Munnell, Webb, Golub-Sass, and Muldoon (2009); and Munnell, Webb, and Fraenkel (2013).

${ }^{2}$ Furthermore, some planning advice suggests that the target replacement rate might have to be higher for households who aspire to a generous lifestyle in retirement or anticipate other large expenditures (such as health or long-term care expenditures for themselves or other loved ones).
} 
projected retirement income replacement rates and compares them to target replacement rates. No doubt the simplicity and transparency of the concept have contributed to its use. Yet a number of issues relevant to economic preparation for retirement are not adequately captured by the replacement rate concept. Specifically,

- Just one-third of full-time workers follow traditional retirement paths transitioning from working full-time to being fully retired. For the other two-thirds, their late-in-life work trajectories involve continued full-time or part-time work, unretirement, unemployment, and disability. For them it is not obvious when to stop measuring income as preretirement and when to start measuring it as post-retirement. The situation becomes substantially more complicated when assessing retirement preparation for couples with two earners.

- People can finance consumption out of savings; most of their savings are not annuitized and so the financing is not recorded as income but as a drawdown of capital.

- The time horizon or survival curve of the household means resources do not have to last indefinitely.

- $\quad$ Spending is reduced following widowing.

- The consumption path is not flat but declines with age (health shocks notwithstanding).

- Taxes differ from pre- to post-retirement and this difference varies by household.

- Households vary in their economic preferences and constraints, with varied implications for resources needed.

The second item on this list is an important example of diversification of income sources, which has in recent decades drawn particular attention to the deficiencies of a simple replacement rate as an indicator of economic preparation for retirement. Formerly, the sum of post-retirement Social Security benefits and pensions (typically with defined benefits, or DB) could be compared with preretirement earnings to yield a replacement rate. This comparison depicted the impact of retirement on income and thus consumption. Today, however, post-retirement income includes sources whose proceeds are not immediately available on retirement and whose receipt is deliberately postponed. Such sources include IRAs and other substantial financial assets without defined benefits.

Scholz and Seshadri (2009) have addressed many of the shortcomings in the income replacement rate. They used a life-cycle model to calculate what a replacement rate should be (the 
"optimal target" replacement rate) and then compared that rate to an income replacement rate as actually observed in data from the Health and Retirement Study (HRS). While they find that their actual calculated average replacement rate of $70 \%$ coincides with the average optimal replacement rates from their model, there is wide dispersion in the specific target, depending on the economic circumstances. Thus a target replacement rate of, say, $70 \%$ could be highly inaccurate for many individuals; that is, inducing some individuals to increase their saving rate to reach the $70 \%$ target would result in their over-saving, yet other individuals already at $70 \%$ ought to increase their saving. This heterogeneity makes the $70 \%$ target a flawed planning tool. We have used the $70 \%$ target as an example because it is often cited, but the statement would be true for other potential target replacement rates. While the Scholz and Seshadri approach is an important alternative to the income replacement rate and quantifies weaknesses in it, there is a need in science and practice for further measures of economic adequacy that are more sensitive to variation among individuals. That is particularly true when arguments for current alternatives seem not very compelling, given that the income replacement rate continues to be in wide use despite its drawbacks.

In this paper we estimate several measures of the income replacement rate that address some of the issues listed above. Then we compare these income replacement rates with a measure of economic preparation for retirement that we previously developed (Hurd and Rohwedder, 2012). This measure, which we call a consumption-based measure of economic preparation, takes into account the complexities of the modern post-retirement income stream and the ultimate consequences for the retirement-to-death consumption path. Broadly speaking, the measure finds whether a household has, with high probability, the resources to finance a trajectory of spending from shortly following retirement until death (in the case of a single person) or until death of the surviving spouse (in the case of a couple). Our method accounts for uncertainty about the date of death, differential mortality, taxes, spending out of assets, marital status, and the consumption path (across time as well as persons). The method takes into account heterogeneity by age, sex, marital status, education, and initial economic conditions. Although Scholz and Seshadri take into account many of the foregoing, we used different data and an entirely different method.

A broad summary of our findings is that our preferred measure of the income replacement rate somewhat understates the percentage of single persons adequately prepared for retirement, but that it grossly understates the percentage of married persons adequately prepared. Furthermore, there is little relationship between the income replacement rate and our consumption-based measure. The implication is that the income replacement rate is of little use for assessing economic preparation for 
retirement: the chances that someone with a low-income replacement rate is well prepared are not much different from the chances that someone with a high-income replacement rate is well prepared.

\section{Methods}

In this section, we describe in more detail our measures of the income replacement rate and how we calculate replacement rates for both single persons and married persons in our sample.

Data

Our data are from the Health and Retirement Study (HRS). The HRS is a biennial longitudinal survey of persons at least 50 years of age. Since its launch in 1992, the HRS has gathered data on income, retirement timing, work, assets, pension plans, health insurance, disability, physical health and functioning, cognitive functioning, health-care expenditures, and such demographic variables as those listed above. Periodic additions of cohorts ensure the HRS remains representative of the population at least 50 years of age. For the consumption-based measure, in addition to the HRS, Hurd and Rohwedder (2012) drew on the Consumption and Activities Mail Survey (CAMS). CAMS is a panel survey supplement to the HRS that measures spending in some 36 categories to arrive at a measure of total spending for a random subset of households in the HRS.

\section{Three variants of the income replacement rate}

We have been referring to the replacement rate, but we used three versions of the income replacement rate. Relative to preretirement earnings we used

1. Actual income conditional on retirement: The latter is the sum of Social Security benefits and DB pension benefits.

2. Everything in version 1, plus an annual drawdown of four percent of financial wealth and IRA wealth, which is a common recommendation among financial advisors

3. Everything in version 1, plus annuity income from other financial wealth and IRA wealth

We observed Social Security and DB pension income from various waves, which allowed us to calculate replacement rates. These calculations differed depending on whether the sampled person was single or married. 


\section{Sample selection}

For this study we began with the sample Hurd and Rohwedder used for their population-based assessment of economic preparation for retirement. That sample was drawn from HRS waves 20022008: individuals both single and married, ages 66-69, and included in CAMS (so that consumption was observed). Further, Hurd and Rohwedder have estimated Social Security benefits and DB pensions income for this sample. For this paper we chose individuals from the Hurd-Rohwedder sample that were observed in some prior wave (going back as far as 1992) to have had earnings when aged 59-61. Thus we can calculate the simple income replacement rate having data on preretirement earnings and on post-retirement Social Security and DB pension benefits.

Estimations for single persons. For selection into the sample, single persons must have been observed working with earnings when ages 59 to 61 . Sample members may have had earnings in up to three waves before age 62 . For each individual, we took an average across waves when earnings were positive to help compensate for any observation error and to account for any years not in the labor force.

The first income replacement rate that we tested (designated $I R R^{3}$ ) was the one in general use, which is obtained by dividing the sum of Social Security and DB pension income ${ }^{4}$ by earnings prior to age 62. To measure earnings (the denominator) we averaged up to three waves prior to age 62 when earnings were positive, giving us a better approximation to permanent earnings than just using one observation on earnings. As for post-retirement income, we recognized that retirees may draw on financial wealth more generally to finance their spending. Two alternative rates were calculated using the IRR construct, but with more inclusive measures of post-retirement income. The first (IRRF) includes in post-retirement income a fixed four percent of financial assets and IRAs. The second of those (IRRA) includes the annuity income from annuitized IRAs and financial wealth as potential sources of funds for retirement spending.

Estimations for married persons. Corresponding estimates of the replacement rate for married persons are more complicated merely by virtue of the need to take account of two persons. One of the two people in a couple, for example, may not have earnings. One may reach retirement at a different age

\footnotetext{
${ }^{3}$ To minimize confusion, "IRR" refers throughout this report only to the measure specifically defined for our purposes under "Methods." Where more generic "replacement rates" or "income replacement rates" are meant, they are written out in lower case.

${ }^{4}$ The measure of DB pension income is the sum of the individual's income from pensions and annuities.
} 
from the other. It is not even obvious what "preretirement income" means in household terms if the difference in ages is substantial.

Our approach was to employ two measures, one person-based and the other household-based. To derive the person-based estimates, we treated each spouse separately, that is, as if they were single persons. This resulted in three measures (IRR, IRRF, and IRRA), as above for singles.

To derive the household-based estimates, we defined the preretirement income of the household as the sum of the preretirement earnings of both spouses (which may be observed in different waves). For post-retirement income, we used the sum of Social Security and DB pension income for both spouses. We designate the ratio of post- to preretirement income, as defined in this paragraph, as CIRR.

In a manner analogous to that for singles, we defined CRRF which adds a four percent annual drawdown from financial assets plus IRAs of both spouses to post-retirement income of the couple. We calculated a third replacement rate, CRRA, by adding the income from annuitizing financial wealth and IRAs of both spouses to Social Security and DB pension benefits.

\section{The consumption-based measure}

Under the consumption-based measure, someone is adequately economically prepared for retirement if, with high probability, he or she dies with positive wealth (Hurd and Rohwedder, 2012). In estimating this measure, Hurd and Rohwedder used data from HRS waves 2000-2008 and from the Consumption and Activities Mail Survey (CAMS). We selected a sample of single and married persons observed at ages 66-69 in HRS data at some point in the years 2000-2008, and asked whether they have the financial resources needed to finance a consumption plan from retirement through the end of life. That plan begins at an observed starting consumption value for each household and follows a path whose shape is determined by observed consumption change with age in panel. Because the age at death is unknown and because wealth is not completely annuitized, someone who dies unexpectedly early may have been adequately prepared ex post, and someone who survives to extreme old age will not have been adequately prepared ex post. To account for this randomness, we used simulation to find the fraction of times ex post that each household was adequately prepared. We stratified by education, sex, and initial marital status because of differential mortality and consumption path shape.

Economic resources are a combination of post-retirement income such as Social Security and pension benefits, housing wealth, post-tax nonhousing wealth, and pretax retirement accounts. The estimations and simulations account for differential mortality risk, and, in the case of couples, the 
lifetime of the couple and the subsequent loss of returns to scale in consumption at the death of the first spouse. The estimations recognize that consumption need not be constant with age, and, in fact, empirically consumption declines with age for single persons. We incorporated the risk of large out-ofpocket spending on health care. We accounted for taxes, which for some households substantially reduces resources available for consumption because of large holdings of tax-advantaged savings. For other households, however, taxes are nil because of the sheltering of Social Security benefits from taxation at low levels of income.

\section{Comparison of adequacy measures}

In our previous work, we found via repeated simulation the fraction of times each person dies with positive wealth and we defined adequate preparation as when that fraction is 0.95 or greater. Table 1 is an extract from that work; it shows the percentage of persons age 66-69 adequately prepared. For example single persons are much less likely to be adequately prepared than married persons: 55\% versus $80 \%$. There is a sharp gradient by education, particularly at the low end of the education distribution. Of particular note is the very low level of preparation among single women who lack a high school degree: just $29 \%$ are adequately prepared.

In this paper we will compare economic preparation as measured by the various income replacement rates with the consumption-based measure. Of interest is the mapping from an income replacement rate to economic preparation for retirement as measured by our consumption-based measure.

\section{Results}

\section{Replacement rates: Single persons}

There were 385 single persons in our simulation sample for whom we observe economic preparation in the age band 66-69 and who had been working at ages 59-61 in a prior HRS wave, enabling us to quantify preretirement income for these respondents. We define and measure income replacement rates for this group, beginning in Figure 1.

The lines in Figure 1 represent the cumulative distributions of replacement rates for single persons. That is, any point on a line shows the percentage of single persons (read off the $y$-axis) having the replacement rate (or less) read off the $\mathrm{x}$-axis. 
The top line shows the distribution of IRR, which is the ratio of post-retirement income (from Social Security and DB pensions only) to preretirement earnings. The median (50 percent on the $y$-axis) corresponds to $\mathrm{x}=0.56$, that is, 50 percent of single people had an IRR of 0.56 or less. Notice some very low IRRs: 17 percent of singles have an income replacement rate of 0.3 or less. Perhaps these individuals have no DB pension and some may not be qualified for Social Security. Some may be wealthy; living off a quantity of personal financial resources is not covered in IRR. In contrast, 80 percent of singles have replacement rates of 1.0 or less, meaning that 20 percent have IRRs of more than 1.0.

As mentioned above, a 70 percent replacement rate is favored by many financial advisors. The cumulative distribution of IRR on the $y$-axis reaches 65 percent for a replacement rate of 0.7 on the $x$ axis. That is, 65 percent of older singles have an income replacement rate of 0.7 or less, implying that 35 percent have a replacement rate of more than 0.7 . This suggests that a majority of single persons are not well prepared economically for retirement, at least by this measure.

The middle line on the graph represents the replacement rate we designate as IRRF, defined above as the ratio of the sum of all economic post-retirement income streams (assets are drawn down at 4 percent per year) to preretirement earnings. The shift of the cumulative distribution to the right implies higher values of the replacement rate for any specified portion of the population. For example, the median for IRRF is 0.67 , versus 0.56 for IRR.

The rightward shift also means that for any specified replacement rate a higher portion of the population will exceed that rate. Thus, for the typical target replacement rate of 0.7 , now 54 percent have a replacement rate that is equal to or less than that, meaning that for IRRF, 46 percent exceed the conventional replacement rate target, up from 35 percent for IIR.

The lowest line of the three is for the replacement rate IRRA, which we define similarly to IRRF, except wealth drawdown is annuitized. This shifts the distribution further to the right. The reason is that annuities produce higher incomes than a fixed 4 percent draw. Now the median corresponds to a replacement rate of 0.74 , and 54 percent have a replacement rate greater than 0.7 .

Thus, regardless of one's perspective on the replacement rate and its utility, just how the replacement rate is measured is important. Here we find a difference of as much as 19 points (54 percent minus 35 percent) across the percentages of people adhering to long-standing advice on achieving income replacement of 0.7. Nonetheless, even under IRRA, the most optimistic replacement 
rate in terms of what is counted as post-retirement income, only 54 percent of single persons are economically prepared for retirement, as measured by having an income replacement rate greater than 0.7 .

We now turn to a comparison of economic preparation for retirement as measured by the various income replacement rates with our consumption-based measure. According to the consumption-based measure of adequate economic preparation for retirement, the fraction of this group with satisfactory preparation is 59 percent (not shown), which is reasonably close to the percent under IRRA with a 0.7 target. However, as shown in Figure $2,{ }^{5}$ the relationship between the income replacement rate and IRR is weak. Only in the lowest replacement rate category (0.0-0.1) and at 0.510.60 is our measure similar to IRS. The reason is that IRR is not influenced by assets; it just depends on preretirement earnings and post-retirement Social Security benefits and pension income. The consumption-based measure of economic adequacy depends importantly on assets because they can be used to finance consumption in retirement.

The consumption-based measure of economic preparation is more strongly related to the other two measures of the income replacement rate, IRRF and IRRA. That is because these income replacement rates depend on assets. Individuals with high levels of assets will have high levels of postretirement income either because of the four-percent drawdown of assets or because of annuitization. People with high levels of assets have a greater likelihood of being economically prepared under the consumption-based measure because those assets can finance a life-cycle consumption path with high probability. Nonetheless, the relationship is far from perfect: For example, among those with an IRRF of 11-20 percent, none of whom would be prepared under an income replacement standard, some 50 percent are economically prepared according to our measure. As with Scholz and Seshadri, our overall level of the average income replacement rate is similar to the average frequency of economic preparation for retirement, but at the individual level there are substantial differences.

\section{Replacement rates: Married persons}

For married persons, the situation is considerably more complex. Issues include the following:

\footnotetext{
${ }^{5}$ The vertical axis in the figure shows the percent adequately prepared according to our consumption-based measure. The horizontal shows the income replacement rate. Thus, for example, among those with an income replacement rate (IRR) of $0-0.10,20 \%$ are adequately prepared according to the consumption-based measure.
} 
- Both spouses work, or only one may work. How is preretirement income to be defined? If they both work, do they share the income equally?

- The age difference within a couple may be substantial: At what age or time should the earnings of both be used when both work? Suppose the husband is 61 and the wife is 52. Are the wife's earnings to be counted when she is 61 (nine years later) or at the same time as her husband's, when she is only 52 ? In the latter case, the couple may not be figuring her earnings into decisions regarding future income and consumption in the same way that they are accounting for his.

- With respect to post-retirement income, each will have Social Security benefits and neither, one, or both will have DB pension benefits. How should these be aggregated?

- When considering a four percent annual drawdown of wealth or annuitization of wealth, how is income to be allocated between spouses? Assets are a household variable, not individually owned.

We considered two ways of looking at preretirement income where couples are concerned. In the first, each spouse is treated as an individual. His or her preretirement income is what he or she earned if working at ages 59-61. That is, the couple is treated as if it were two singles. In the second perspective, spouses are treated as a couple. We do this only if the age difference is no more than five years and if at least one spouse is working at ages 59-61. Then, the couple's preretirement income is the sum of what each spouse was earning at ages 59-61. Thus, in this treatment, "retirement" refers to the retirement of either or both spouses. Because their age difference is five years or less, we can assess the preretirement earnings of each spouse at approximately the same time (within a maximum of five years).

For each treatment of preretirement income, we define three measures of post-retirement income (corresponding to IRR, IRRF, and IRRA in the discussion of single persons, above), resulting in six measures of income replacement rate. The following table shows the measures, along with the nomenclature we use in referring to them. Note that, for IRRF and IRRA, each married person gets 50 percent of the income resulting from drawing down the assets of the couple. For CIRRF and CIRRA, the couple is treated as a joint entity and the assets as joint assets. 
Nomenclature for replacement rates

\begin{tabular}{lcc}
\hline & \multicolumn{2}{c}{ Treatment of married persons } \\
\cline { 2 - 3 } Post-retirement income & Like single persons & As a couple \\
\hline Social Security + DB pensions & IRR & CIRR \\
SS + DB pensions + 4\% of financial assets and IRAs & IRRF & CIRRF \\
SS + DB pensions + annuity from financial assets and IRAs & IRRA & CIRRA \\
\hline
\end{tabular}

Figure 3 shows the cumulative distributions for the three income replacement measures when couples are treated as singles. The overall pattern is the same as for single people (Figure 1): an increasing income replacement rate moving from IRR to IRRF to IRRA, evidenced by a rightward shift in the curves. Specifically, the medians are at income replacement rates of 0.44 (IRR), 0.54 (IRRF), and 0.59 (IRRA). But while the pattern is similar, the numbers are different. The medians for singles are 0.56 , 0.67 , and 0.74 , respectively. Thus, by these individual-based measures, married persons are worse off financially than single persons.

To further compare single and married persons regarding income replacement rates, we determined the percentages of people making the cutoff for the rate conventionally viewed as indicating adequate preparation (more than 0.7; the data in the singles column have already been presented). The following table shows the percentages of people with an income replacement rate greater than 0.7 . Thus, for example, using the IRRA construct, 54 percent of singles have an adequate income replacement rate, an advantage of 13 percentage points over married persons, only 41 percent of whom have an adequate replacement rate of more than 0.7 .

Percent of persons with income replacement rates greater than 0.7

\begin{tabular}{|l|c|c|}
\hline & Single persons & Married persons \\
\hline IRR & 35 & 25 \\
\hline IRRF & 46 & 35 \\
\hline IRRA & 54 & 41 \\
\hline
\end{tabular}


As the table indicates, in all replacement rate concepts singles are better prepared than married persons. Furthermore, for the IRRF and IRRA concepts, where the increase in income from assets is added to Social Security and pensions, singles' advantage is perhaps greater than it is for IRR.

The results of these analyses are counter to conventional thinking, which anticipates higher post-retirement incomes for married persons than for single persons. But these higher-income replacement rates for single persons are actually due to their considerably lower preretirement earnings, not due to higher post-retirement incomes.

The analysis in Figure 3 is performed for married people treated as singles. Figure 4 shows income replacement rates defined at a household level; that is, the earnings of both spouses determine preretirement income, and the incomes of both spouses determine post-retirement income. This measure shows an advantage of couples over singles: there are fewer instances in which we observe a post-retirement income that is very low.

Figure 4 exhibits the same pattern as do the individually based analyses in Figures 1 and 3: a rightward shift, as increasing income from assets is added into post-retirement income. Here we see higher income replacement rates than when married persons are treated as individuals. For example, median CIRR, CIRRF, AND CIRRA are 0.53, 0.67, and 0.75, respectively. Thus, as measured by CIRRA, taking a household viewpoint increased the median replacement rate from 0.59 (Figure 3) to 0.75 (Figure 4).

Despite the large increase in economic preparation from using the household approach instead of the single-person approach to measure income replacement, married persons are no better off than single persons as measured by the median income replacement rate. Among singles, for example, IRRA is 0.74 , whereas among couples it is 0.75 . The same holds true for other measures. The inability of the income replacement rates to distinguish between the economic preparation of singles and couples argues against their use more generally for comparatively assessing economic preparation for retirement.

\section{Consumption-based measure of adequate economic preparation for retirement}

We now compare income replacement rates with our consumption-based measure (see Figures 5 and 6). In Figure 5 each married person is treated as an individual. Some 80 percent of married persons are 
adequately prepared according to our consumption-based measure. The percent that, according to the income replacement rate, is adequately prepared depends on the measure, but IRRF would be most comparable. ${ }^{6}$ According to IRRF only 35 percent of people are adequately prepared (have an IRRF greater than 0.7$)$. The line relating IRR to the fraction of married persons adequately prepared has a small positive slope, indicating that those with greater income replacement rates have somewhat better preparation according to the consumption-based measure. But the relationship is weak. For example, among those with an IRR of 0-0.1, none of whom are adequately prepared according to the IRR, 68 percent have adequate preparation for retirement according to the consumption-based measure. The relationship is somewhat stronger with IRRF and IRRA because they account for wealth in defining postretirement income and the consumption-based measure also does. Even there, though, the relation is still not very strong. For example, among those with an IRRA of $0.11-0.20$, some 71 percent are prepared according to the consumption-based measure; among those with an IRRA of 0.91-1.00, some 88 percent are prepared.

Figure 6 shows the relationship between income replacement rate and the consumption-based measure of preparation when income is aggregated at the household level. The relationship between the consumption-based measure and the income replacement rates remains weak. If adequacy of economic preparation is to be defined as an income replacement rate of more than 0.7 , then 46 percent are economically prepared (based on CIRRF; see Figure 4), whereas the consumption-based measure indicates that 81 percent are adequately prepared (Figure 6).

\section{Summary and Conclusions}

The income replacement rate (income immediately following retirement divided by earnings immediately preceding retirement) is widely used as a measure of economic preparation for retirement by financial advisors and in the popular financial literature. Yet a number of issues have been identified that are not adequately addressed by the replacement rate concept.

The income replacement rate is well suited to account for such resources as Social Security and DB pensions. However, in planning for retirement, workers must now account for other, often less predictable economic resources. The DB plans of the $20^{\text {th }}$ century have been largely replaced by

\footnotetext{
6 IRRA includes a "mortality return" that is not included in the consumption-based measure, making IRRA not directly comparable.
} 
defined-contribution plans, whose values depend not only on contributions, but also on movements in the markets in which the plans are invested. Many people possess other forms of financial wealth that are not always thought of as sources of income but that could serve as such.

Post-retirement income options have also diversified to the extent that both spouses work. Now, one household may have two earners with retirement ages that differ, either because the two differ substantially in age, or because one prefers to retire at a different age than the other. Furthermore, some workers now have part-time options and can move among various income-earning states. Given the complexity that a second earner adds, it is not clear how to determine the timing of a couple's retirement and quantify their pre- and post-retirement income.

In this paper we have considered three variations of the IRR to account for some of the complexities of the contemporary labor and investment markets available to workers near retirement age. To address IRAs and other sources of post-retirement income, we assumed an annual four-percent drawdown of financial assets and IRAs - a rate considered prudent by financial advisors. This allowed us to account for possession of financial wealth, which resulted in considerable improvement to economic preparation for retirement. (We designated this modified replacement rate as IRRF.) We also tried annuitizing these income sources (expressed in a replacement rate designated IRRA), but, although this resulted in even higher levels of preparation for retirement, annuitization of assets such as IRAs is rarely done. For the purposes of our analyses, then, the four-percent drawdown is more relevant, and that is what we have used for comparing income replacement rates with a consumption-based measure.

To address the increase in two-earner households, we took two approaches. First, we treated each spouse separately as a single person, so each had his or her own income replacement rate, drawn, in the case of IRR, from his or her own preretirement earnings and post-retirement Social Security and pension income. In the case of IRRF, the replacement rate also took account of the four-percent drawdown of financial wealth and IRAs, split into two equal shares.

Second, we treated the spouses as a couple, jointly. In this approach, each married individual existed for our purposes only as an element of a couple, which was indivisible until the marriage dissolved, through death or otherwise. There were only household preretirement earnings and household post-retirement income. This was the approach we preferred. It recognizes the realistic advantages of pooling income, and is likely to yield a more meaningful measure of economic preparation for retirement. (We 
designated income replacement rates for the couple-based analyses as CIRR and CIRRF, analogous to IRR and IRRF, above.)

These adjustments to IRR generated higher levels of preparation for retirement. For example, the following table conveys the percentage economically prepared across our whole sample. Considering the post-retirement income sources recognized by IRR, little more than a third of the respondents surveyed were economically prepared for retirement. But when IRAs and other wealth elements were recognized as potential income sources, as specified for IRRF (or CIRRF), a considerably higher 46 percent were prepared. The criterion for a single, a married person, or a couple to be regarded as "prepared" was possession of an income replacement rate of more than 0.7 .

Percent economically prepared for retirement

\begin{tabular}{|l|l|l|l|}
\hline \multicolumn{2}{|c|}{ Single persons } & \multicolumn{2}{c|}{ Married persons } \\
\hline IRR & 35 & CIRR & 34 \\
\hline IRRF & 46 & CIRRF & 46 \\
\hline Consumption-based & 59 & Consumption-based & 81 \\
\hline
\end{tabular}

Based on an income replacement rate of more than 0.70

Our main purpose in this paper is to further develop and apply a consumption-based measure of economic preparation and compare the results to measures of economic preparation based on measures of income replacement rates. The consumption-based measure is theoretically preferable because consumption is more likely to translate directly into well-being than is income, which has to be consumed. Our estimated consumption-based measure indicates retirement preparation at 59 percent of single persons, well over those derived from income replacement rates. For couples, the consumption-based retirement preparation rate is a much higher 81 percent.

It is noteworthy that only the consumption-based measure conveys the expected retirement-age financial advantage of couples over single people. The advantage that we see in retirement preparation reflects differences in both income and wealth. Mean reported post-retirement income is twice as high for couples as for singles (see the following table). Mean reported financial wealth, including IRAs, is three times as much for couples as for singles. These multiples may actually understate the advantages accruing to couples. Because of returns to scale, couples do not need to spend twice as much as singles to be as well off. For example, the structure of spouse and survivor benefits under Social Security 
recognizes returns to scale. In the simplest one-earner case, the couple's benefit would be $1.5 \times$ PIA and the survivor's benefit would be $1.0 \times$ PIA. Under equal sharing of income, the structure implies that a married person needs just 75 percent of the income of a single person to be as well off. Furthermore, as married persons become widowed, and if we assume that the survivor inherits the wealth of the deceased spouse, the survivor will tend to have similar levels of wealth supporting lower streams of consumption.

\begin{tabular}{|l|c|c|}
\hline & $\begin{array}{c}\text { Mean post-retirement } \\
\text { income }(\$ 1000 \text { 's) }\end{array}$ & $\begin{array}{c}\text { Mean financial wealth } \\
+ \text { IRAs }(\$ 1000 \text { 's) }\end{array}$ \\
\hline Singles & 24.4 & 118 \\
\hline Couples & 49.9 & 344 \\
\hline
\end{tabular}

The lack of a sensible or anticipated relationship between singles' IRRs or IRRFs and those of couples argues against putting much stock in these ratios as indicative of retirement preparation adequacy. The consumption-based measure does differ in the expected way across singles and couples. Moreover, as shown in Figures 5 and 6, there is little relationship between the income replacement measures and the consumption-based measures. Adequacy of preparation as measured by the consumption-based measure does not increase substantially with increasing income replacement ratio, regardless which specific ratio is used.

Our conclusion is reflected in ongoing changes in the financial advice industry. While income replacement rates have been used widely until recently in online financial planning tools, several companies have moved away from this concept. Instead they suggest households first try to predict their lifestyle in retirement, acknowledging that this may vary a lot across households. For example, the Fidelity retirement planning tool now starts out by querying the individual about the household's expected expenses in retirement. ${ }^{7}$ The Merrill Lynch retirement planning page first queries the individual about life goals and priorities to determine spending needs and investment risk profiles of the individual. $^{8}$ This move toward determining expenses in retirement and comparing them with the

\footnotetext{
${ }^{7}$ https://www.fidelity.com/retirement-planning/envision-your-retirement

8 https://www.ml.com/retirement-planning.html?gclid=ci6epb6cmcgcfysyhwodx7qgbq\#fbid=VWVCbUMhuq?cm mmc=GWM-MLAdvisory- -Google-PS- -retirement\%20planners- -Plan\%20-\%20Phrase
} 
household's income and asset portfolio to assess whether the household's resources can support that lifestyle is conceptually much closer to the approach we put forward in the consumption-based measure of retirement adequacy. 


\section{References}

Au, Andrew, Olivia S. Mitchell and John W. R. Phillips. 2004. “Modeling Lifetime Earnings Paths: Hypothetical versus Actual Workers." Working Paper 2004-3. Boettner Center for Pensions and Retirement Research.

Biggs, Andrew G. and Glenn R. Springstead. 2008. "Alternate Measures of Replacement Rates for Social Security Benefits and Retirement Income," Social Security Bulletin, Vol. 68 No. 2, 2008.

Boskin, Michael J., John B. Shoven. 1984. “Concepts And Measures Of Earnings Replacement During Retirement", NBER Working Paper Series, \#1360.

Brady, Peter J. 2008. "Measuring Retirement Resource Adequacy," Investment Company Institute.

Hurd, Michael D. and Susann Rohwedder. 2012. "Economic Preparation for Retirement." Investigations in the Economics of Aging. D. A. Wise. Chicago, The University of Chicago Press: 77-113.

Munnell, Alicia H. and Mauricio Soto. 2005. "What Replacement Rates Do Households Actually Experience in Retirement?" Center for Retirement Research Working Papers, August 2005.

Munnell, Alicia H., Anthony Webb and Rebecca C. Fraenkel. 2013. "The Impact of Interest Rates on the National Retirement Risk Index," Center for Retirement Research at Boston College. June. Issue Brief Number 13-9.

Munnell, Alicia H., Anthony Webb and Luke Delorme. 2006. “A New National Retirement Risk Index," Center for Retirement Research at Boston College Issue Brief, No. 48.

Munnell, Alicia H., Anthony Webb, Francesca Golub-Sass and Dan Muldoon. 2009. "Long-Term Care Costs and The National Retirement Risk Index," Center for Retirement Research at Boston College. January. Issue Brief Number 9-7. 
Munnell, Alicia H., Francesca Golub-Sass and Anthony Webb. 2007. "What Moves the National Retirement Risk Index? A Look Back and an Update." Center for Retirement Research at Boston College. January. Issue Brief Number 7-1.

Scholz, John Karl, Ananth Seshadri, and Surachai Khitatrakun. 2006. "Are Americans Saving 'Optimally' for Retirement?" Journal of Political Economy, 114(4), August: 607-643.

Scholz, John Karl and Ananth Seshadri. 2009. "What Replacement Rates Should Households Use?" Michigan Retirement Research Center Working Paper 2009-214. 
Table 1. Percent adequately prepared: 95 to 100 percent chance of dying with positive wealth after reducing consumption by $10 \%$

\begin{tabular}{lcccccc}
\hline & \multicolumn{3}{c}{ Single Persons } & \multicolumn{3}{c}{ Married Persons } \\
\hline & All & Males & Females & All & Males & Females \\
\hline Less than high-school & 36.0 & 63.6 & 29.0 & 70.1 & 70.2 & 69.9 \\
High-school & 62.1 & 66.7 & 60.5 & 79.5 & 77.2 & 80.8 \\
Some college & 53.8 & 62.5 & 51.0 & 80.7 & 77.2 & 82.6 \\
College and above & 68.5 & 65.0 & 69.6 & 88.5 & 86.5 & 90.2 \\
All & 54.5 & 64.9 & 51.3 & 79.9 & 77.9 & 81.1 \\
\hline
\end{tabular}

Source: Hurd and Rohwedder, 2012 


\section{Figures}

Figure 1. Cumulative distributions (percent) of replacement rates; single persons

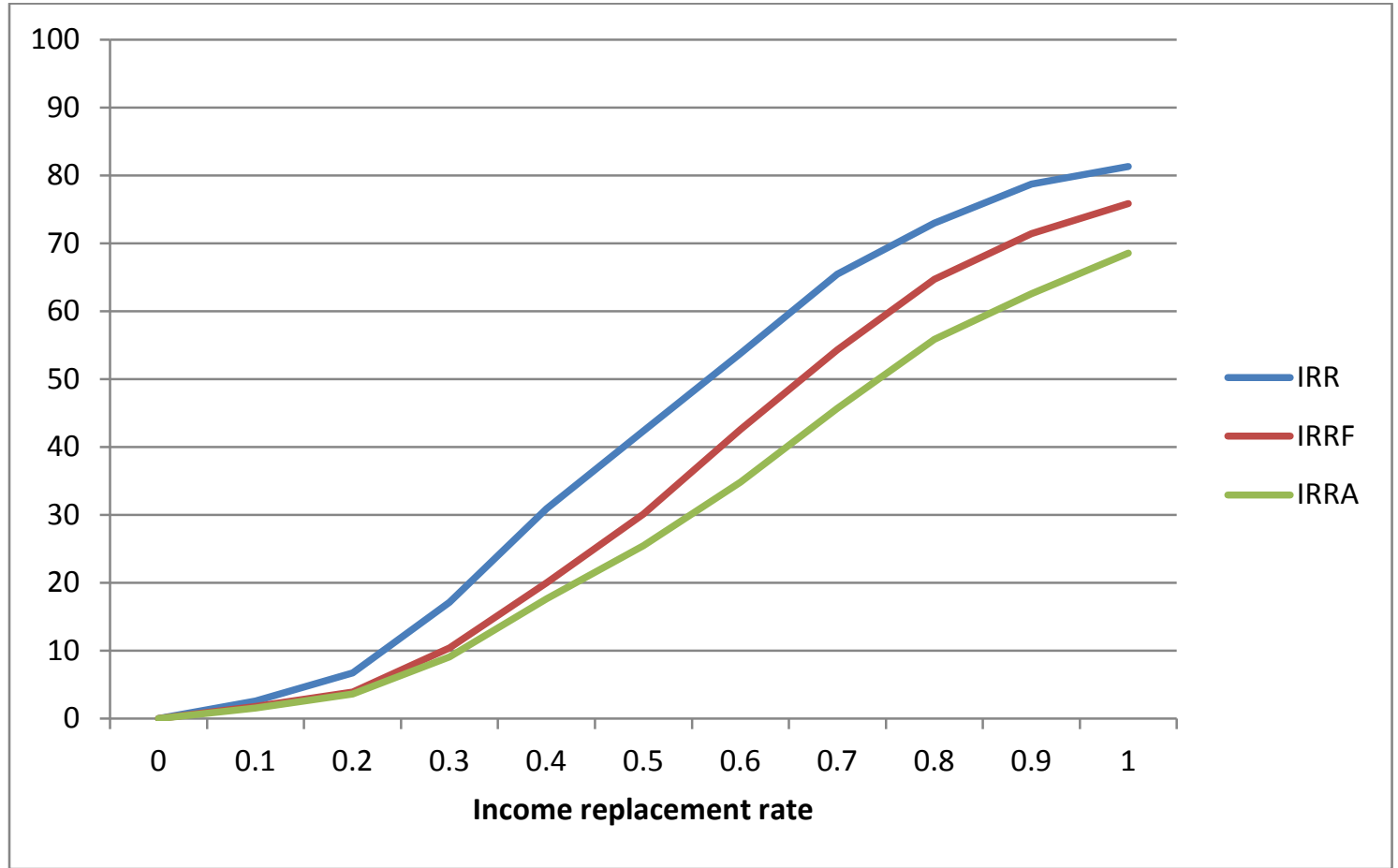

Notes:

$\mathrm{IRR}=$ Social Security + pension income after retirement divided by earnings preretirement

IRRF adds four percent of financial wealth (including IRAs) to numerator of IRR.

IRRA adds income from annuitizing financial wealth (including IRAs) to numerator of IRR. 
Figure 2. Percent adequately prepared according to consumption-based measure, singles

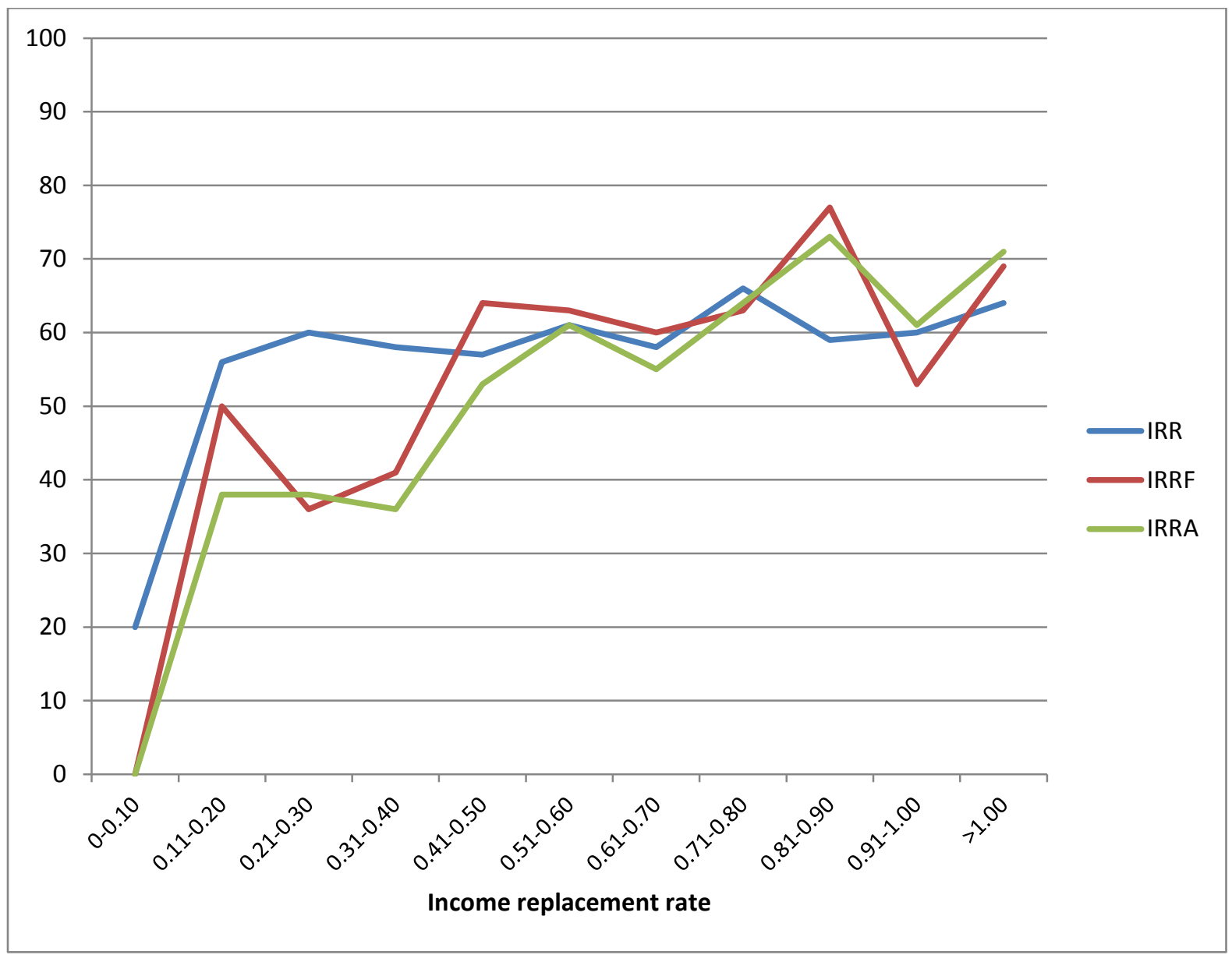

Notes:

IRR = Social Security + pension income after retirement divided by earnings preretirement IRRF adds four percent of financial wealth (including IRAs) to numerator of IRR.

IRRA adds income from annuitizing financial wealth (including IRAs) to numerator of IRR. 
Figure 3. Cumulative distributions (percent) of replacement rates; couples; each spouse treated as an individual

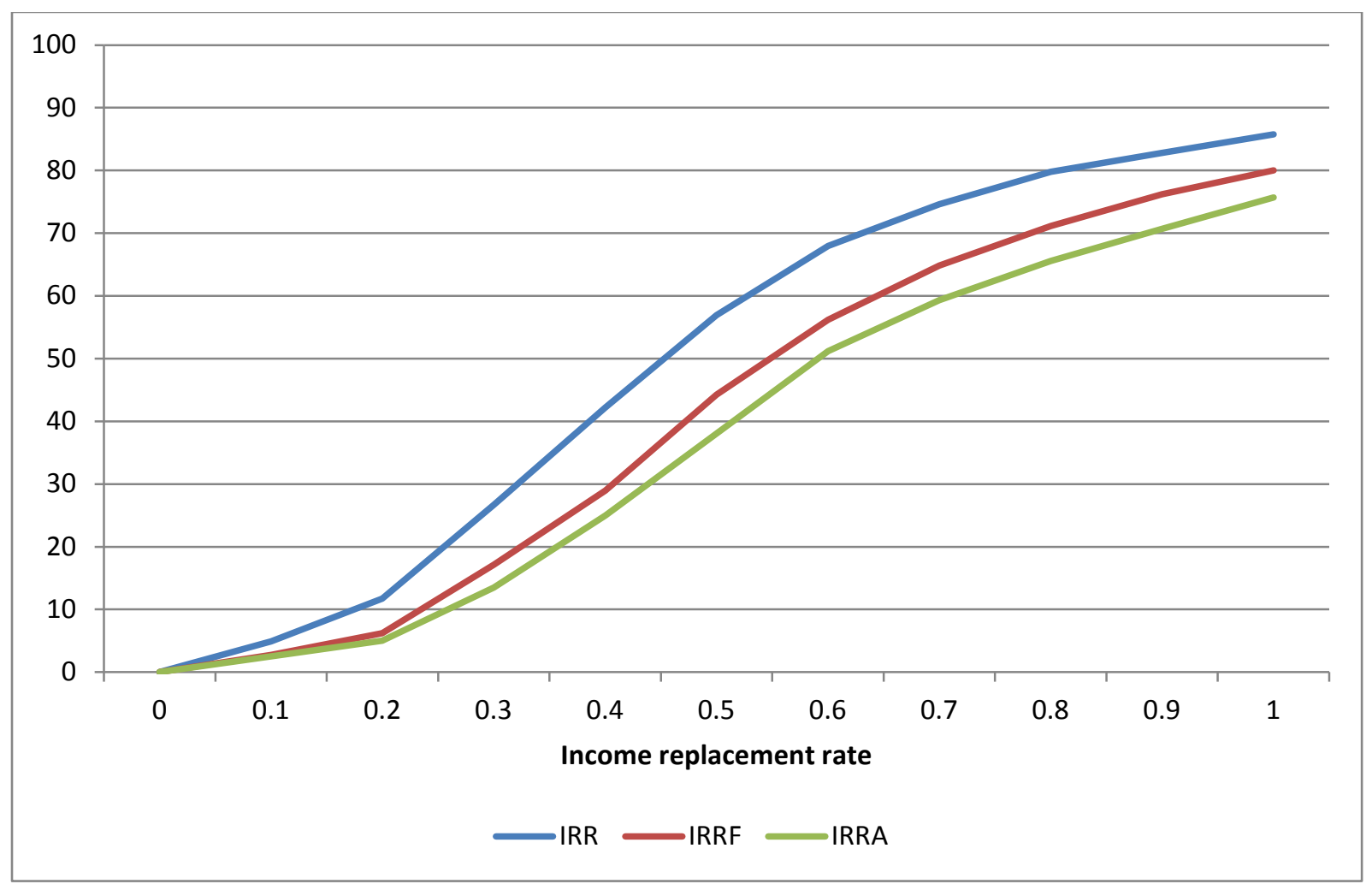

Notes:

IRR = Social Security + pension income after retirement divided by earnings preretirement

IRRF adds four percent of financial wealth (including IRAs) to numerator of IRR; $50 \%$ allocation to each spouse.

IRRA adds income from annuitizing financial wealth (including IRAs) to numerator of IRR; $50 \%$ allocation to each spouse. 
Figure 4. Cumulative distributions of replacement rates; couples; household income

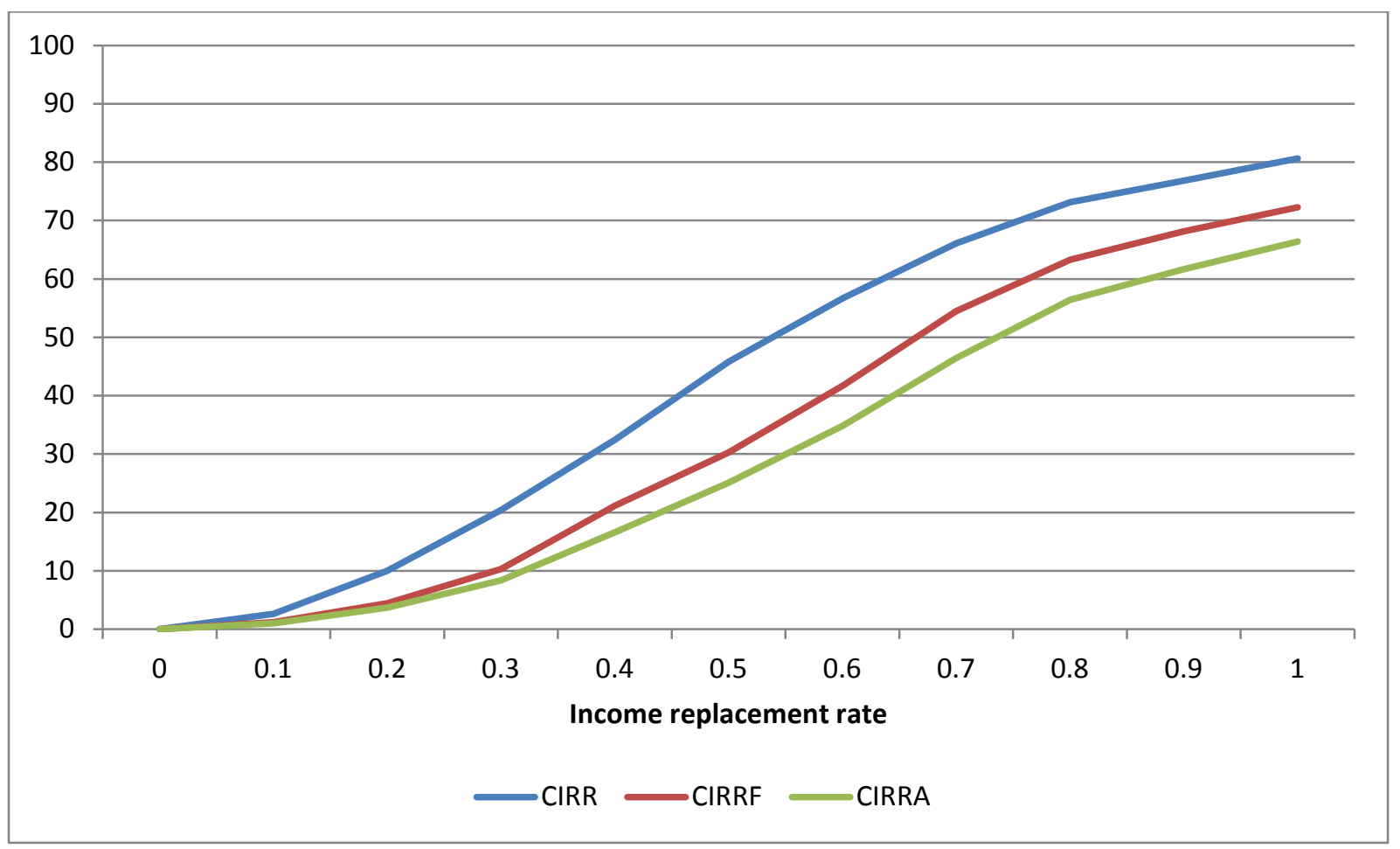

Notes:

$\mathrm{CIRR}=$ Social Security + pension income after retirement divided by earnings preretirement CIRRF adds four percent of financial wealth (including IRAs) to numerator of CIRR.

CIRRA adds income from annuitizing financial wealth (including IRAs) to numerator of CIRR. 
Figure 5. Percent adequately prepared according to consumption-based measure, couples; each spouse treated as an individual.

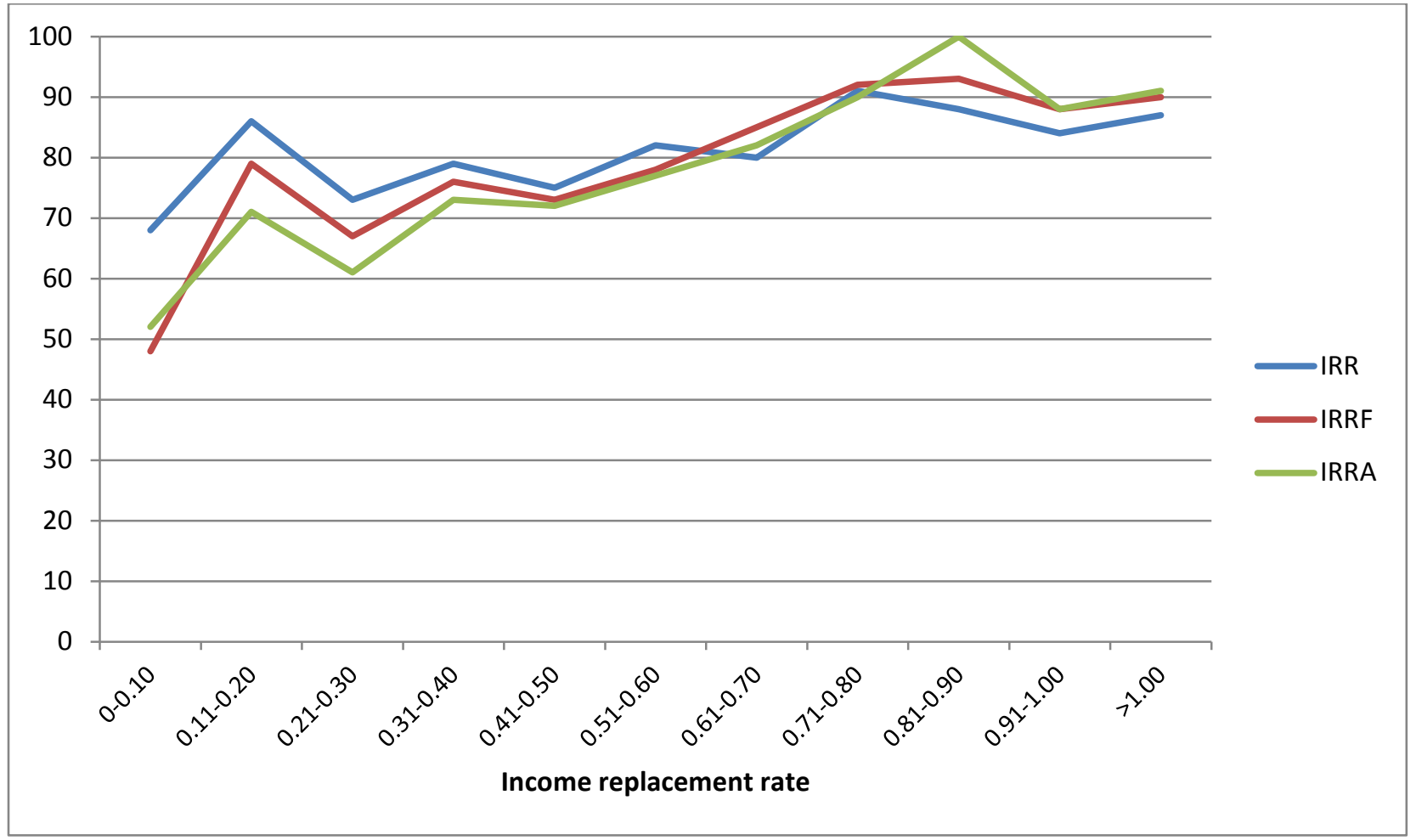

IRR = Social Security + pension income after retirement divided by earnings preretirement

IRRF adds four percent of financial wealth (including IRAs) to numerator of IRR; $50 \%$ allocation to each spouse.

IRRA adds income from annuitizing financial wealth (including IRAs) to numerator of IRR; $50 \%$ allocation to each spouse. 
Figure 6. Percent adequately prepared according to consumption-based measure, couples, household income

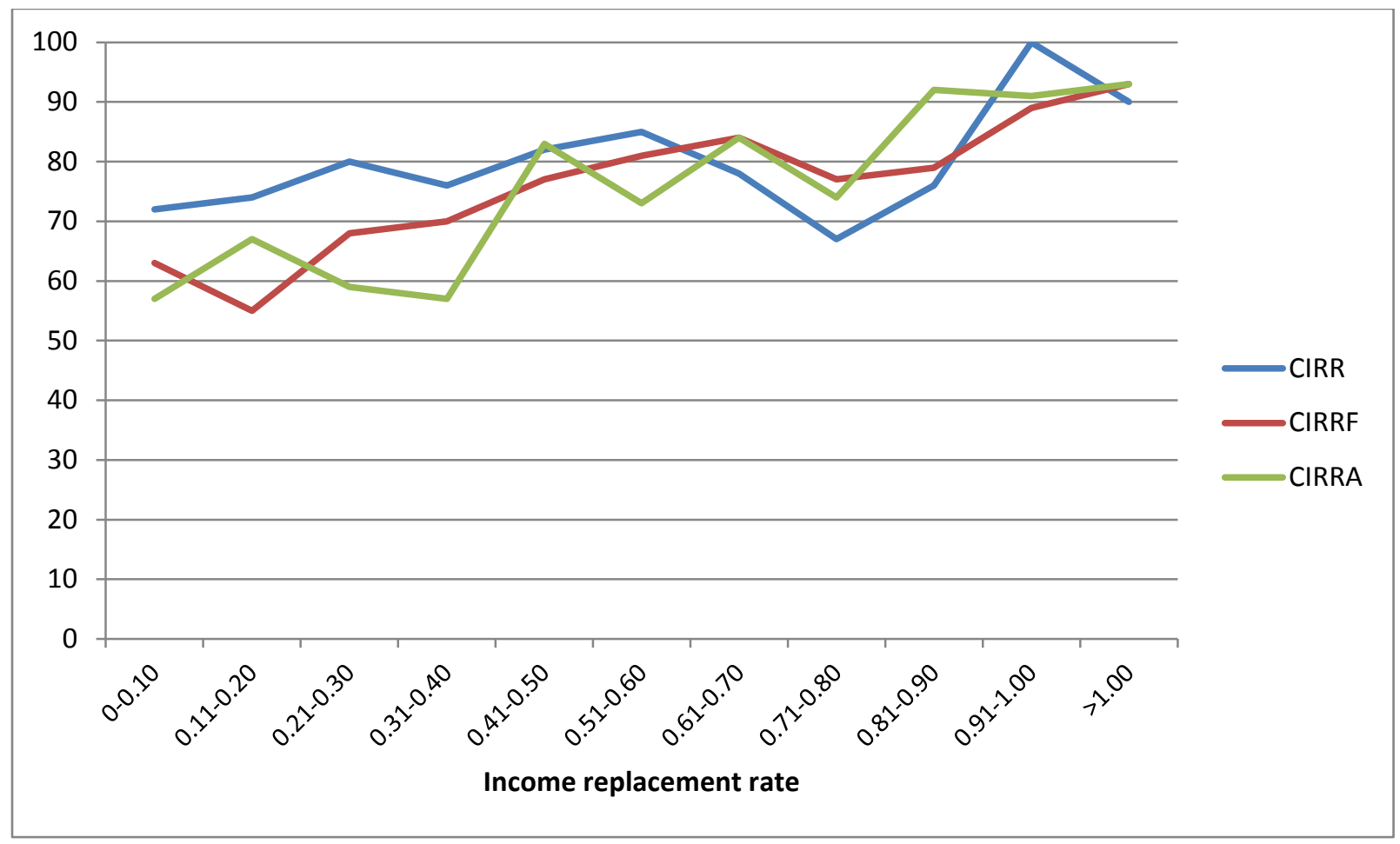

Notes:

CIRR = Social Security + pension income after retirement divided by earnings preretirement CIRRF adds four percent of financial wealth (including IRAs) to numerator of CIRR CIRRA adds income from annuitizing financial wealth (including IRAs) to numerator of CIRR 